Lixuan Jiang, Hua Zhong, Jianghong Chen, Zhenmin Su, Jinhua Zhang, Xiao Wang,(2019). "Lean construction practice: culture, standardization and informatization — A case from China." In: Proc. $27^{\text {th }}$ Annual Conference of the International. Group for Lean Construction (IGLC), Pasquire C. and Hamzeh F.R. (ed.), Dublin, Ireland, pp. 949-960. DOI: https://doi.org/10.24928/2019/0274.. Available at: <www.iglc.net>.

\title{
LEAN CONSTRUCTION PRACTICE: CULTURE, STANDARDIZATION AND INFORMATIZATION - A CASE FROM CHINA
}

\author{
Lixuan Jiang1, Hua Zhong ${ }^{2}$, Jianghong Chen ${ }^{3}$, Zhenmin $\mathrm{Su}^{4}$ Jinhua Zhang ${ }^{5}$, and \\ Xiao Wang ${ }^{6}$
}

\begin{abstract}
Many construction enterprises in the world are practicing lean construction and benefiting from it. China, with a big construction industry, has promoted lean concepts in recent years, but there are still obstacles in practice. The aim of this study therefore is to introduce a Chinese construction company, demonstrating some the most successful lean construction outcomes in China.

A case study approach is used with whole process of the project's implementation being tracked. Data are collected from interviews, meetings and statistics. The study shows that three important aspects collaboration lead to the success of lean construction implementation. Relationships among culture, standardization and informatization are explored. The study recommends a lean culture frame of employee value and customer value integration and incentives providing. Standardization is employed as Work structuring tool to provide operability and offer the foundation to informatization. Last Planner®system (LPS) practice is aided by an hour level precision control to improve efficiency. This research presents a case for improving lean construction effectiveness in Chinese context.
\end{abstract}

1 Associate Professor, Cailiang Lean Construction Research Center, Department of Construction Management and Real Estate, School of Economics and Management, Nanjing Tech University, China, +8625-58139570, jianglx@ njtech.edu.cn

2 Senior Lecturer, Center for Lean projects, Building Services School of Architecture, Design and Built Environment Nottingham Trent University, UK, 01158482557, hua.zhong@ntu.ac.uk

3 Associate Professor, Cailiang Lean Construction Research Center, Department of Construction Management and Real Estate, School of Economics and Management, Nanjing Tech University, China, +8625-58139570, njchenjianghong@163.com

4 Professor, Director of Cailiang Lean Construction Research Center, Department of Construction Management and Real Estate, School of Economics and Management, Nanjing Tech University, China, +8625-58139570, suzhenmin@126.com

5 General manager, Engineer, Cailiang Lean Construction Research Center, Cailiang construction technology co., Ltd., China, +86519-68202089, zhangjh_1513@163.com

6 Professor, Cailiang Lean Construction Research Center, Department of Construction and Management, School of Civil Engineering, Nanjing Tech University, China, +8625-58139488, wangxiao@njtech.edu.cn 


\section{KEYWORDS}

Lean construction, China practice, culture, standardization, informatization.

\section{INTRODUCTION AND LITERATURE REVIEW}

In recent years, the development speed of Chinese construction industry is very fast, but the quality can be low. Delays, cost overruns and quality problems are still common in the industry (Bristow M. 2007; Ng E. 2013; Li Shuquan et al. 2017). Lean thinking is identified as an alternate management philosophy to improve construction productivity (Koskela 1992; Egan 1998). The concepts and ideas of lean construction have been introduced into China (Zhenmin Su 2004; Qinghua He 2013; Shuquan Li 2014; Meigui Han 2015); however, the practice is still fragmented.

In 2017, Jiang Su Province took the lead in issuing Jiangsu Construction 2025 Action Outlines, which pointed out that lean construction, digital construction, green construction and prefabricated construction will be vigorously promoted in the future. Some large stateowned construction enterprises in China, such as the Third and Eighth Engineering Division of China Construction, have already begun pioneering the use of lean construction. However, it is used in a Chinese context have not been well studied. The Chinese construction industry comprises many poorly managed, small and medium construction enterprises (Duan Zongzhi 2007; Hu Weifei 2018). The challenge is to enable industry participants accept the lean idea and implement it effectively (Gao S. et al. 2013; Li Shuquan et al. 2017).

Issues around knowledge and culture are some of the main obstacles to successful lean implementation (Alienate HM 2009; Sarhan S. 2012). Green (1998) first highlighted the cultural implications of lean implementation, noting that

"Every improvement initiative directed at the construction sector tends to be accompanied routinely be exhortations in favor of an associated cultural change" (Green, 2011).

Culture is an area of interest in construction industry (Fellows 2010) for its impacts on project performance (Casson 1993; Adenfelt and Lagerstrom 2006). However, there is little evidence of detailed research on lean culture frame and its work mechanism.

Construction industry in China has been accused of culture shortage and refusing changes (Yang et al. 2004; Zhang S.B. 2006). Recognizing problems of labor force shortage and mobility, lower educated workforce, rough management and inefficiency, defaulting on workers' wages etc. still afflict the industry (He xuefei 2011; Guodong Dai 2013; Gao S. et al. 2013), and the need for a better understanding of the culture issue will help promote lean construction implementation in China.

Koskela (2000) explored lean theory through the integration of transformation, value and flow (TFV), with the concept further developed by Howell and Bertleson (2001). According to the Lean Construction Institute (LCI), the decomposition of work activities through Work Breakdown Structure (WBS) is at odds with TFV though its application contributes specially to project success (Halli 1993). WBS forms an element of the Critical Path Method (CPM) which emphasizes activity dependency relationships without enough focus on the flows of works, locations or resources. So Work structuring was proposed to 
serve as a framework for achieving integrated product-process design, appropriate for the TFV concepts (Howell and Ballard 1999). Nevertheless, Work structuring is a very new concept to Chinese construction industry.

Last Planner ${ }^{\circledR}$ system (LPS) is the most powerful and well-known planning and control system of all the lean construction techniques and tools (Kenley and Seppänen 2010). LPS's purpose is to produce a predictable workflow, and "pulling" as a new way of introducing information and/or materials into a building process is introduced to improve workflow and create sound process (Ballard, Howell 2000; Koskela 2000; Kalsaas, Grindheim and Læknes 2014).

LPS has provided good outcomes yet there is little in depth investigation of LPS practice in China (Gao S. Low 2012; Shuquan Li 2014). Elements such as culture, Work structuring and information technology etc. should not be neglected, as lean construction is a system thinking mindset (Koskela 2000; Ballard and Tommelein 2016).

\section{METHODOLOGY AND METHODS}

Although there is some research on lean construction by Chinese scholars (Zhenmin Su 2004; Qinghua He 2013; Shuquan Li 2014; Gao S. Low 2012), yet there are no case studies related to project performance or success factors of implementation. The qualitative method was considered appropriate, as lean concept may be new to most of Chinese building professionals. Then a case study approach is used in this paper. As a pioneer of lean construction practitioner in China, the company and its Jiuzhou Garden residential project No.58 building are studied as one of the most successful lean construction cases in China. The whole process of implementation was tracked. Data were collected from interviews, meetings and statistics.

In order to present a complete process and give evidence of lean practice in Chinese construction industry, yet offer lean knowledge contribution from China, a collaboration model with three key success factors is explored, and hypotheses on their relationship and interactions are discussed.

\section{Case Study}

\section{Case background}

The project is in the north of Hu-Ning Expressway of Changzhou City, Jiang Su Province, China. No.58 building comprises 30-story frame shear wall structured housing including one below-grade floor, with a total area of 21,000 square meters. This project is researched because of its experimental use of lean practices. Lean methods and tools such as $5 \mathrm{~S}$ onsite management, LPS, Work structuring, Value management, Visual management and Takt planning are used.

\section{Contrast sample group}

In contrast six other buildings constructing in traditional way concurrently were used as sample group. The case study project and the contrast sample buildings makeup of the whole residential project of 142,000 square meters. Every building is the same size and 
construction with only difference in organizational methods. None of those above mentioned lean tools are applied in the contrast sample group.

\section{COLLABORATION MODEL AND HYPOTHESES}

\section{The framework of the collaboration model}

Three key success factors are summed up in the case project and the company, which are culture, standardization and informatization. Figure 1 reveals the relationship among them with a collaboration model.

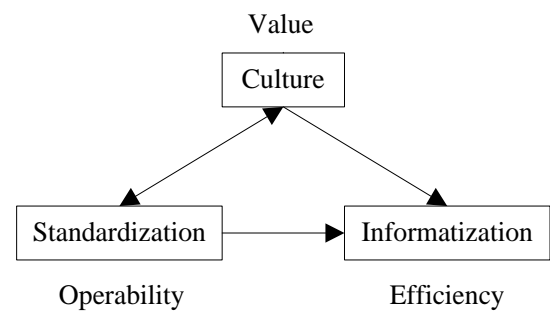

Figure 1: A collaboration model of three key factors

Successful lean practices require a cultural change to unleash the power of workforce or change the way people think(Ted Angelo 2010; Jorge Izquierdo 2010; Keiser J.A. 2012), as a saying of Sanford Smith (2011), "If you don't embrace the culture, you will not get it right." Therefore, culture is hypothesized to play a leading role in the lean construction implementation, ensuring the dissemination of lean ideas and values, guiding the direction and normalization of employees' behavior.

Standardized work (SW) is a type of action-oriented procedure that is an essential element of lean management systems (Ohno 1988). Further, standardization means the process of a series of Standardized work realization and improvements (Gibb 2001). In the case company, standardization offers operability and aids scientific management by obtaining data from repeatedly time study and action research, further aided by advanced information technology to achieve improved efficiency outcomes.

Informatization is defined as the process of cultivating and developing new productive forces by intelligent tools (The first National Information work Conference of China 1997). In this paper, informatization refers to the process of employing computer technology, network technology and so on to aid lean tools to improve efficiency.

\section{Hypotheses}

The relationship among culture, standardization and informatization has gradually become clearer and been strengthened along with the lean construction implementation and exploration in the company. There are three hypotheses as follows:

- Hypothesis 1: Culture has positive effects on Standardization and provides incentives for employees.

- Hypothesis 2: Standardization fills the gap between lean culture and the operability, also forms the foundation of informatization.

- Hypothesis 3: Culture has positive effects on informatization by promoting employee skills upgrading to improve efficiency. 


\section{CULTURE}

The lean journey of this company began with cultural change and development, and lean culture serves as direction and supports of lean construction implementation. Customer value of zero quality defects and employee value of cultivating people are integrated to act the leading role of lean culture in the company.

\section{CUSTOMER VALUE CULTURE WITH ZERO QUALITY DEFECTS}

The lean strategy advocator and leader of the company insists on craftsman spirits spreading and a high-quality housing as core value of lean construction culture. Craftsman spirit is a kind of professional spirit which is the embodiment of professional ethics, ability and quality. It is also a kind of professional value orientation and behavior performance of practitioners. The basic connotation of "craftsman spirit" includes professional, lean, focused, innovative and so on (Chinese Civilization website 2017). Putting customer value first and setting up zero quality defect goal are implemented throughout the project and satisfied consumers with zero quality complaints. The company has won a high reputation for its residential products with few defects, in contrast to the high of housing complaints reported in China.

\section{EMPLOYEe VALUE CULTURE WITH CULTIVATING PEOPLE}

Cultivating people is the other core spirit of the lean culture. People cultivation contains four main elements:

- Create clean and safe project work environments

- Enhance the professional dignity

- Strengthen the professional quality of managers and operation workers

- Pass on and mould craftsman's spirit in construction industry

Lean culture in this company is composed of four parts: the surface layer of Company Image System (CIS); the shallow layer of employee behavior requirements; the middle layer of management and operation work standardization; and the deep layer of doublecore value of both customer and employee.

It takes a long time for Lean concepts acceptance and culture development. It's found in the case practice that lean culture and standardization should act on each other to help employees' behavior change and quality improvement.

\section{STANDARDIZATION}

Ballard (1999) initially equated the term "Work structuring" to process design, which serves the three goals of production systems: do the job, maximize value, and minimize waste (Ballard, Koskela, Howell 2001). WBS is a description of the project's scope, deliverables and outcomes. In order to design the process and the schedule to reduce waste and improve value, an appropriate level of detailed work breakdown and process optimization are needed. Standardization as a process optimal method is considered to be a part of Work structuring, based on the deepening WBS to optimize both process and value. Six parts consist of the standardization with ultimate goals of waste elimination, on 
time delivery, as well as quality, safety, and cost improvements are reached. Figure 2 reveals a framework combining WBS, Work structuring and standardization.

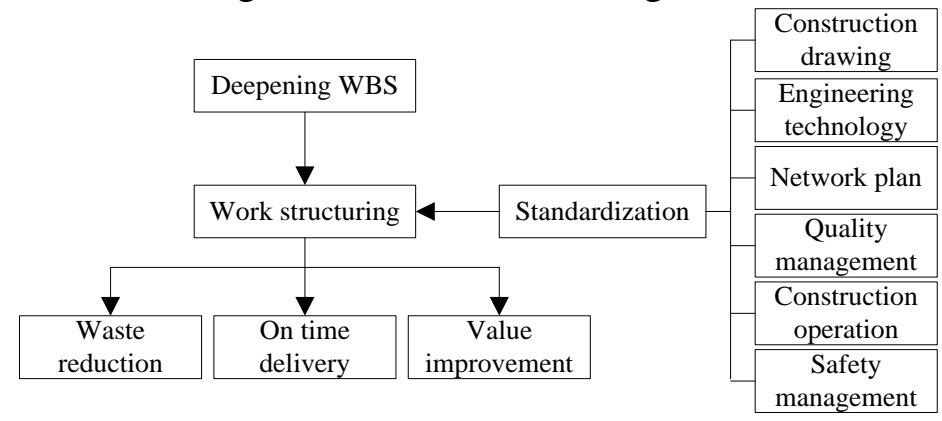

Figure 2: The framework of WBS, Work structuring and standardization

\section{DEEPEN AND REFINE FOR WBS}

In case of No.58 building, efforts have been made to refine the WBS approach in order to develop sufficiently detailed and appropriate criteria for residential construction building. The total amount of decomposed works accumulated more than 1,000 items, which are discussed by experienced project managers.

The deepening WBS is featured in: Work sequence depth; WBS-OBS integration; WBS-LPS mapping; Logical relationship improvement; and Optimization of construction technology. Based on the logically optimized broken down sub-terms, experiments on time and action study are done, and data are collected for criterion written. Managers and workers are trained for the new broken down items and the criterion.

\section{STANDARDIZATION AS TOOLS FOR WORK STRUCTURING}

Although Work structuring has been advocated to align with product and process in construction and a guide proposed, further systematic experimentation with concepts and techniques is needed (Howell and Ballard 1999, 2000; Ballard, Koskela, and Howell, 2001). More than one decade of exploration in the company has developed six parts of standardization as tools for Work structuring to improve operational level practice of lean construction.

- Construction drawings standardization

Standardization of construction drawings contains design refining and optimization. In order to eliminate waste such as rework, conflicts and contradictions among different disciplines, cross functional group was set up to work together to standardize the construction drawings.

In case of No.58 building, there had only 101 construction drawings originally, after team work efforts of construction drawing detailing, the number of drawings are accumulated into 1,023, of which 407 are civil works and 616 are water and electricity.

\section{- Standardization of engineering technology}

From repeated experiments and demonstration, the "Residential process Standards" (24 books in all) are formed. All of these criteria are summarized and optimized on the basis of construction practices and experiences. More than ten items are contained in every process node, such as progress requirements, construction preparation, operating standards, 
safety facilities, coordination person, green construction requirements, resource allocation, inspection and acceptance criteria, etc.

- Network plan standardization

Basing on the refined WBS, No.58 building was broken down into 1,587 activities from temporary facilities arrangement to completion and acceptance.

LPS was used to optimize the plan and control process. Construction tasks are arranged in detail to 0.5 days and workers are demanded strictly by precise start time and finish time in the scheduling.

- Quality management standardization

Three aspects are enhanced to guarantee building quality by standardization as mentioned above. Construction drawing standardization ensures construction quality from the source. Innovative craft methods are explored to deal with common quality problems. Standard working procedures help to reduce defects, and downstream work can begin only after upstream-work meeting the criterion and being accepted.

\section{- Construction operation standardization}

In order to supply operation workers with a precise guideline to reduce repairs or reworks, save materials and improve equipment efficiency, construction operation standards are developed.

Experiments are carried out for data collection. Enterprise quotas are formed to present clearly standards of every procedural in manpower requirements; material and machine consumption; and cost measurement.

- Safety management standardization

The construction site was arranged according to the CIS standards. 5S on-site management is employed. Enterprise logos, the workers' clothing, and the staff dormitories are unified to offer workers a clean, tidy, safe and dignified working space. Construction safety standards are aided by visualization technology. Three-dimensional graphics library of 16 sub modules are developed to provide site safety guiding.

In view of these, the case company's standardization has proposed a path for Work structuring to offer operability and deliver high quality products to the customers.

\section{INFORMATIZATION}

\section{AN HOUR LEVEL PRECISION CONTROL ON LPS IMPLEMENTATION}

A schedule management software and Co-office platform are developed, with precision to an hour level control. Pull mechanism of look-ahead planning connecting with commitment planning contributes to LPS effectiveness, and the hour level control system improved the efficiency. The weather forecast is embedded in the software to get nearly $100 \%$ of the percent plan complete (PPC).

\section{Precision control on an hourlevel}

Managers are authorized to query, upload data and issue instructions in the schedule management system. Foremen and operation workers are provided with APP use on the mobile phone. Task information about start and end time, quantities, tool use and resource 
requirements is conveniently transferred. Table 1 shows one of the operating interfaces of the hour level control of scheduling.

Table 1: An hour level control of scheduling

\begin{tabular}{|c|c|c|c|c|c|c|c|c|c|c|c|c|c|}
\hline $\begin{array}{c}\text { Project } \\
\text { Procedures }\end{array}$ & $\begin{array}{c}\text { Working } \\
\text { hours }\end{array}$ & Team & Examiner & \begin{tabular}{|l|}
$\begin{array}{l}\text { Operation } \\
\text { standards }\end{array}$ \\
\end{tabular} & $\begin{array}{c}\text { Acceptance } \\
\text { criteria }\end{array}$ & \begin{tabular}{|c|}
$\begin{array}{c}\text { Detection } \\
\text { method }\end{array}$ \\
\end{tabular} & \begin{tabular}{|c|}
$\begin{array}{c}\text { Monitoring } \\
\text { frequency }\end{array}$ \\
\end{tabular} & \begin{tabular}{|c|} 
Safety \\
precautions
\end{tabular} & $\begin{array}{c}\text { supervision or } \\
\text { coordination }\end{array}$ & \begin{tabular}{|c|} 
Rules for \\
Calculating \\
Quantity \\
\end{tabular} & \begin{tabular}{|c|}
$\begin{array}{c}\text { Other } \\
\text { standards } \\
\text { attachment }\end{array}$ \\
\end{tabular} & Remarks & $\begin{array}{c}\text { Examina } \\
\text { tion }\end{array}$ \\
\hline Preparation & $1.50 \|$ & $\begin{array}{c}\text { Project } \\
\text { department }\end{array}$ & $\begin{array}{l}\text { Primary structure } \\
\text { inspection group }\end{array}$ & See details & See details & See details & $\begin{array}{l}\text { Check before } \\
\text { concrete } \\
\text { pouring }\end{array}$ & See details & $\begin{array}{l}\text { Builder, Security } \\
\text { officer, } \\
\text { Crane driver et.al }\end{array}$ & & $\underline{\text { Link }}$ & $\begin{array}{l}6.1 \text { Formwork } \\
\text { inspection batch } \\
\text { acceptance record }\end{array}$ & 1 \\
\hline \begin{tabular}{|c} 
Ash damper \\
cleaning, wet \\
and hanging \\
\end{tabular} & $0.50 \Pi$ & $\begin{array}{c}\text { Concrete } \\
\text { team }\end{array}$ & $\begin{array}{l}\text { Primary structure } \\
\text { inspection group }\end{array}$ & See details & See details & See details & Patrolling & & $\begin{array}{l}\text { Security officer, } \\
\text { Quality staff }\end{array}$ & See details & $\underline{\text { Link }}$ & $\begin{array}{l}\text { Photos uploading } \\
\text { and records } \\
\text { retention } \\
\end{array}$ & 4 \\
\hline $\begin{array}{c}\text { Formwork clear } \\
\text { and watering }\end{array}$ & $0.50 \prod$ & $\begin{array}{c}\text { Concrete } \\
\text { team }\end{array}$ & $\begin{array}{l}\text { Primary structure } \\
\text { inspection group }\end{array}$ & See details & See details & See details & Patrolling & & $\begin{array}{l}\text { Builders, Quality } \\
\text { staff }\end{array}$ & See details & $\underline{\text { Link }}$ & $\begin{array}{l}\text { Photos uploading } \\
\text { and records } \\
\text { retention }\end{array}$ & 1 \\
\hline $\begin{array}{c}\text { Mortar } \\
\text { back to pump }\end{array}$ & $1.30 \Pi$ & $\begin{array}{c}\text { Concrete } \\
\text { team }\end{array}$ & $\begin{array}{l}\text { Primary structure } \\
\text { inspection group }\end{array}$ & See details & See details & See details & Patrolling & & \begin{tabular}{|l|} 
Builder, Security \\
officer, \\
Crane driver et.al
\end{tabular} & See details & $\underline{\text { Link }}$ & $\begin{array}{c}\text { Photos uploading } \\
\text { and records } \\
\text { retention }\end{array}$ & 1 \\
\hline $\begin{array}{c}\text { Concrete pouring } \\
\text { and vibration }\end{array}$ & of 10.00 I & $\begin{array}{c}\text { Concrete } \\
\text { team }\end{array}$ & $\begin{array}{l}\text { Primary structure } \\
\text { inspection group }\end{array}$ & See details & See details & See details & Patrolling & See details & $\begin{array}{l}\text { Builder, Security } \\
\text { officer, } \\
\text { Crane driver et.al }\end{array}$ & See details & $\underline{\text { Link }}$ & $\begin{array}{c}\begin{array}{c}\text { Photos uploading } \\
\text { and records } \\
\text { retention }\end{array} \\
\end{array}$ & 1 \\
\hline $\begin{array}{c}\text { Mold } \\
\text { observation }\end{array}$ & 10.00 【 & $\begin{array}{c}\text { Woodworking } \\
\text { team }\end{array}$ & $\begin{array}{l}\text { Primary structure } \\
\text { inspection group }\end{array}$ & & & & & & & $\begin{array}{l}\text { Calculated by } \\
\text { floor area }\end{array}$ & & & 1 \\
\hline \begin{tabular}{|c|} 
Reinforcement \\
observation \\
\end{tabular} & 10.00 & $\begin{array}{c}\text { Reinforcement } \\
\text { team }\end{array}$ & \begin{tabular}{|l} 
Primary structure \\
inspection group
\end{tabular} & & & & & & & $\begin{array}{l}\text { Calculated by } \\
\text { floor area }\end{array}$ & & & 1 \\
\hline $\begin{array}{c}\text { Water } \\
\text { and electricity } \\
\text { observation }\end{array}$ & $9.70 \|$ & \begin{tabular}{|c}
$\begin{array}{c}\text { Hydropower } \\
\text { installation } \\
\text { team }\end{array}$ \\
\end{tabular} & $\begin{array}{l}\text { Primary structure } \\
\text { inspection group }\end{array}$ & & & & & & & $\begin{array}{l}\text { Calculated by } \\
\text { floor area }\end{array}$ & & $\begin{array}{l}\text { Photos uploading } \\
\text { and records } \\
\text { retention }\end{array}$ & 1 \\
\hline $\begin{array}{l}\text { Recycling of } \\
\text { ground ash }\end{array}$ & $8.70 \|$ & $\begin{array}{c}\text { Concrete } \\
\text { team }\end{array}$ & $\begin{array}{l}\text { Primary structure } \\
\text { inspection group }\end{array}$ & See details & See details & See details & Patrolling & & $\begin{array}{l}\text { Builder, Security } \\
\text { officer, } \\
\text { Crane driver et.al }\end{array}$ & See details & $\underline{\text { Link }}$ & $\begin{array}{l}\text { Photos uploading } \\
\text { and records } \\
\text { retention }\end{array}$ & 1 \\
\hline $\begin{array}{c}\text { Ash damper } \\
\text { cleaning } \\
\text { and recycling }\end{array}$ & 10.20 & $\begin{array}{l}\text { Concrete } \\
\text { team }\end{array}$ & $\begin{array}{l}\text { Primary structure } \\
\text { inspection group }\end{array}$ & See details & See details & See details & Patrolling & & \begin{tabular}{|l|} 
Builder, Security \\
officer, \\
Crane driver et.al
\end{tabular} & See details & $\underline{\text { Link }}$ & $\begin{array}{l}\text { Photos uploading } \\
\text { and records } \\
\text { retention }\end{array}$ & 1 \\
\hline
\end{tabular}

\section{The pull mechanism of look-ahead planning}

Pull planning was implemented through positive task preparations basing on the standardization of engineering technology, construction operation, quality and safety management etc. Accurate 'tasks made ready' to remove constraints are pulled by downstream requirements including purchase and the resource organization.

\section{Commitment planning}

Operation workers have been trained in technical, quality and safety guidance before work start along with clear informed in working contents, time, location etc from the mobile phone APP. Commitment planning is guaranteed by workers beginning with their works on time with materials at hand which are prepared by auxiliary workers. As the reverse commitment, they will be paid as soon as the tasks are completed on time and accepted by inspection, and it makes a great incentive.

\section{BIM APPLICATION}

BIM technology was used throughout the construction process, supporting for modeling and amounting, field layout, measure model, construction model, deviation adjustment and process model. It is to be mentioned that the BIM use is not yet universal in Chinese construction industry, data exchanges among disciplines remain difficult, so BIM application in this case study contributes mainly in visual communication and supplementary optimization.

\section{HYPOTHESES VALIDITY}

Evidences are collected through survey, interviews or chats with on-site workers to check up the hypotheses as follows. 


\section{HYPOTHESIS 1 AND 2 VALIDITY}

The double core culture concepts builds consensus among employees, assisting lean thinking acceptance, with employees more willing to change and getting involved in improvement. Culture effectiveness is reached rather by providing incentives and operability.

In contrast to most of dirty and messy construction sites in China, site of the case project is tidy and clean benefiting from $5 \mathrm{~S}$ implementation, construction workers stated, "willing to work in such comfort site though tough demanded".

Zero quality defect goal was achieved by strict operation standards and every stage of standardization, thus to fill the gap between culture and operability. Most on-site workers expressed "we are willing to work under such tough standards if we are told clearly enough, because less rework and few repairs will happen, and we are paid promptly".

Standardization develops process standards and employee behavior norms to improve productivity and quality to reach three goals of Work structuring. All standardization offer more opportunities to labor workers to improve constructability and quality.

Standardization optimizing on every stage of waste reduction, constraints removing and value improvement together with data collections offers the foundation of informatization. An hour precision control can't be reached if it is separated from this foundation.

\section{HYPOTHESIS 3 VALIDITY}

Peoples' willing to change and involve in is an important part of the culture. Accordingly, informatization is proved to improve efficiency not only by transparent and convenient communication but by facilitating employees' skills upgrading. Most of the workers indicated that they "are pleased to cooperate in data acquisition and testing of operating standards and to use information tools" and appreciated "both increased wages and decent work". The site manager also declared that "once workers are used to using task assignments APP and inquiring on craft methods database, management works will be reduced while safety and quality being better guaranteed".

\section{DISCUSSION}

No.58 building started to construct on 18th August 2015 and delivered on 25th March 2017, the case company undertook the project as the general contractor. Compared with the traditional mode, it shortened the duration by 104 days with a shorten rate of $19.62 \%$; skilled worker employing was saved by $16 \%$, and the labour cost was reduced by $2.33 \%$; the total cost save rate was $2.88 \%$. The performance comparison between No.58 building and traditional samples is illustrated in table 2 below. LPS practice supported by an hour level precision control contributes to duration saving, and standardization taken as Work structuring tools results in quality and safety improvement. There presents more orderly and cleaner construction site and energetic workers in the case project in contrast to the contrast sample group.

The case study also provides some new insights that how lean construction implementation can be adopted in Chinese construction industry. The practice case 
investigates that lean culture should offer incentives to play a guiding role. As cultural shift is a long-term process, filling the gap between culture and the operability is necessary.

The lean exploration of this company has given some answers. Firstly, lean value concepts should be deeply embedded in the culture of both enterprise and project, influencing the employee's behavior norms, and providing incentives. Secondly, efforts should be made to supply workers with convenience to improve efficiency and quality. Finally, Lean Construction needs to embrace emerging technologies to make work more productive.

Table 2: Performance comparison between No.58 building and traditional samples

\begin{tabular}{cccc}
\hline Compared item & Contrast samples & No.58 & Improvement rate \\
\hline Duration & 530 day & 426 day & $19.62 \%(-)$ \\
Skilled labour & 369 & 310 & $16.00 \%(-)$ \\
Labour cost & $6,390,300(\mathrm{RMB})$ & $6,241,600(\mathrm{RMB})$ & $2.33 \%(-)$ \\
Total cost & $26,437,960(\mathrm{RMB})$ & $25,675,957$ ( RMB $)$ & $2.88 \%(-)$ \\
Quality & $/$ & Zero quality defect & $/$ \\
Safety & $/$ & Zero safety accident & $/$ \\
\hline
\end{tabular}

\section{CONCLUSION}

The purpose of this paper is to introduce a lean construction practice in China, from which a collaboration model is developed to reveal the relationship between three key factors. Culture and people are thought to be the most important elements in the case practice. The effective leadership of the company plays the key role of success. The advocator and leader as a soul figure together with a high executive team has created company-wide cultural transformation and lean implementation. People are incentive to accept lean concepts and provided with convenience to take actions. Standardization, as an exploration of Work structuring, is tried to connect TFV theory with traditional tool of WBS to guide operations. Informatization makes it possible to realize LPS implementation on an hour level precise control. All of these have important enlightenment and demonstration significance for promoting lean construction in China.

Further studies are needed to investigate other more companies and projects to experiment the model validity. Moreover, the findings are limited to the contractor practice of lean construction, with few effects to the design stage. Future research will focus on transferring lean ideas from contractors to designers, subcontractors and suppliers to promote the change of the whole industry chain.

\section{ACKNOWLEDGMENT}

We would like to thank Cailiang construction technology Co., Ltd and the project team for the cooperation and providing access to data collection and investigation. 


\section{REFERENCES}

Ballard, G. (1999). "Work structuring”. LCI White Paper, 5.

Ballard, H.G. (2000). "The last planner system of production control." Doctoral dissertation, University of Birmingham.

Ballard, G., Koskela, L., Howell, G., Zabelle, T. (2001). "Production System Design in Construction." In: Proc. 9th Ann. Conf. of the Int'l. Group for Lean Constr., Singapore, Aug 6-8, 1-15.

Ballard, G., Hammond, J. and Nickerson, R., (2009). "Production control principles." In: Proc. 5th Ann. Conf. of the Int'1. Group for Lean Constr., Taipei, Taiwan, Jul. 15-17.

Bertelsen, S. (2001). "Lean construction as an integrated production." In: Proc. 9th Ann. Conf. of the Int'l. Group for Lean Constr., Singapore, Aug 6-8.

B. L. Chesworth. (2012). "Cultural Maturity Modelling for Lean Organisations.” Doctoral dissertation, University of Newcastle

Bristow M. (2007). "China's Construction Projects 'Rushed"”. BBC NEWS, UK.

Chinese Civilization website. (2017). "On the Spirit of Crafts.” May 24.

Duan Zongzhi, Zhou Jiansheng. (2007). "Discuss on the Market Structure of Chinese Building Industry." Optimization of Capital Construction.28 (5):56-59.

Egan J, (1998). "Rethinking Construction.” Department of Environment, Transport and the Region, UK Government.

Fellows, R., (2010). Understanding Organisational Culture in the Construction Industry. Construction Management and Economics, 28 (8), 898-900.

Green S D, (1998). "The Technocratic Totalitarianism of Construction Process Improvement: A Critical Perspective." Engineering Construction \& Architectural Management, 5(4), 376-386.

Green, S. D. and May, S. C. (2005). "Lean Construction: Arenas of Enactment, Models of Diffusion and the Meaning of 'Leanness." Building Research and Information, 33 (6), 498-511.

Gao, S., Low, S. P., Hwang, B. G., \& Ofori, G. (2012). "Lean construction in large Chinese construction firms: A SWOT analysis." Proceedings of the CIOB World Construction Conference 2012, Colombo, Sri Lanka, 28-30 June.

Gao S., S P., (2013), "Understanding the application of Kaizen methods in construction firms in China", Journal of Technology Management in China, 8(1):18-33

Gibbs, A.G.F. (2001). "Standardization and pre-assembly-distinguishing myth from reality using case study research." Construction Management and Economics, 19 (3), 307-315.

Guodong Dai. (2013). "The tendency and influencing factors of future labour force supplies for building industry." Doctoral dissertation, Zhe Jiang University.

He xuefei. (2011). "Research on the Relief System of Migrant Worker's Salary Rights in China's Construction Industry". Doctoral dissertation, China University of Political Science and Law.

Kalsaas, B.T., Skaar, J. and Thorstensen, R.T., (2015). "Pull vs. push in construction work informed by Last Planner." In Proc. 23rd Ann. Conf. of the Int'l. Group for Lean Construction. Perth. Australia, Jul 29-31, 103-112. 
Keiser, J.A. (2012). "Leadership and Cultural Change: Necessary Components of a Lean Transformation" In Proc. 20nd Ann. Conf. of the Int'l Group for Lean Constr., San Diego, USA, Jul 18-20.

Koskela, L. (1992). "Application of the New Production Philosophy to Construction." Technical Report 72, CIFE, Stanford University, CA.

Koskela L, (2000). "An exploration towards a production theory and its application to construction". VTT Technical Research Centre of Finland

Li, S., Wu, X., Zhou, Y., \& Liu, X. (2017). "A study on the evaluation of implementation level of lean construction in two Chinese firms." Renewable and Sustainable Energy Reviews, 71, 846-851.

$\mathrm{Ng}$ E. (2013). China's construction giants cut down to size in foreign projects. South China Morning Post.

Ohno, T. (1988). "Toyota Production System: Beyond Large Scale Production." Productivity Press, Cambridge, MA.

Pasquire C.L. \& Court, P.F (2013). "An Exploration of Knowledge and Understanding-the Eighth Flow." In Proc. 21st Ann Conf. of the Int'l Group for Lean Construction, Forteleza, Brazil, Aug 31-2, 43-52.

Pasquire C.L. et al. (2017). "Shared Understanding: The Machine Code of the Social in a Socio-Technical System." In Proc. 25rd Ann. Conf. of the Int'1. Group for Lean Construction. Heraklion.Greece, Jul 9-12, 365-372.

Qinghua He et al. (2017). "The Theory Development and Operation Methods of Lean Project Delivery System: A Literature Review." Journal of Engineering Management.27 (5), 1-5.

Seddon J and Caulkin S, (2007). "Systems thinking lean production and action learning, Action Learning: Research and Practice." 4(1), 403-419.

Shuhong Jiang, Zhenmin Su (2004). "Lean Construction: A kind of Advanced System of Construction." Optimization of Capital Construction.25 (3), 11-16.

Stevens, M. (2014). "Increasing adoption of lean construction by contractors". In Proc. 22nd Ann. Conf. of the Int'l Group for Lean Construction, Oslo, Norway, Jun 25-27, 377-388.

Tsao, C. C., Tommelein, I. D., Swanlund, E. S., \& Howell, G. A. (2004). "Work structuring to achieve integrated product-process design.” ASCE, J. Constr. Eng. Manage., 130(6), 780-789.

Tommelein, I. D., \& Ballard, G. (1997). "Look-ahead planning: screening and pulling." Seminário Internacional sobre Lean Construction, 2, 20-21.

Zhang, S.B., Liu, A.M.M., (2006). "Organizational culture profiles of construction enterprises in China." Constr. Manag. Econ. 24 (8):817-828. 